\title{
FACTORS AFFECTING THE QUALITY OF RESEARCH PROCESSES
}

\author{
Henryk DŹWIGOŁ \\ Silesian University of Technology, Gliwice (Poland); London Academy of Science and Business, London \\ (United Kingdom); Sumy State University, Sumy (Ukraine); henryk.dzwigol@poczta.fm, \\ ORCID: 0000-0002-2005-0078
}

Purpose: The aim of the article was to determine main factors that would influence the quality of a research process, as an element that supplements currently used methodology-related approaches.

Design/methodology/approach: Following the fulfilment of the objective, the research was carried out with the help of a questionnaire addressed to the theoreticians of management sciences (401 representatives) being a target group. Moreover, in order to measure the factors determining the quality in management sciences, eight factors determining the quality of the research process were identified on the basis of the conducted factor analysis, which were subsequently described.

Findings: On the basis of the factor analysis, eight factors determining the quality of the research process were identified, i.e.:

- Practical application and purposefulness.

- Influence of diverse research problems on the process.

- Influence of a researcher on the research process.

- Unique character of a scientific discipline.

- Importance of observations.

- Completeness of the process.

- Process assistance type.

- Need for triangulation and universalism.

Research limitations/implications: The conclusions of the analysis concerning the methodology of conducting the research process indicate a lack of empirical approach to the problem of the quality of the research process, where as a result of the transformations taking place over the years in the methods of management, it is difficult to choose one single method allowing to conduct a full and thorough diagnosis of the problem already at the stage of defining the research problem. Therefore, the research undertaken in the article aims to identify factors influencing the quality of the research process as an element complementary to the existing methodological approaches.

Practical implications: The management methodology is constantly being extended with new methods characterized by different cognitive and practical efficiency. The constant growth of diagnostic instruments is primarily conditioned by changes in the environment, and is also related to the need to use increasingly sophisticated and effective tools.

Social implications: The conclusions of the analysis concerning the methodology of conducting the research process are reflections on the transformations that have taken place over the years in the management methods, that allow exploring the state of the organization. 
Originality/value: Depending on the subject matter the researcher has undertaken in his or her scientific work, some of these factors do not necessarily have to be reflected and diminish its importance in science and practice. These factors are determinants that allow assessing the quality of the conducted research process. The notion of the quality of the research process in management sciences is understood as the possibility of verifying the degree of realization and coherence of the goals of the work with the research problem and conclusions described in it.

Keywords: Research process quality, research methodology, research methods and techniques.

\section{Introduction}

Dynamic changes in the organization's environment force companies to integrate, develop and reconfigure their internal and external competencies in order to respond to a rapidly changing environment (Teece et al., 1997). These capabilities are particularly important where innovation is equated with creative destruction of existing competencies. Examples of dynamic capabilities offered within the branch-related literature include responding to market needs, rapid and flexible product innovation, technological capabilities and R\&D intensity (Karna et al., 2016). However, the current theoretical framework focusses only on what companies are doing and not why they are doing it (O'Leary and Hunt, 2016; Petrova, 2018).

A rapid introduction of new, recommended management-related concepts and methods, as well as their fast rejection resulted in negative organisational changes (Coghlan and Shani, 2016; Harrington, 2016). It would be difficult to identify the reasons why the applied methods were ineffective. Was the failure triggered by an inadequate method used for a management process or by its unskilful implementation (Dźwigoł, 2018).

It needs to be stated that, in spite of critical views, both management sciences and their methods and methodology result in the improved effectiveness and competitiveness of companies. However, it needs to be mentioned that management methods are not and cannot be of universal character. The methods must be changed as the times goes by, as the company changes over the years (Punch, 2016; Quian, 2018).

In modern management science, research and analyses focus mainly on the quality of the research process. The latter influences the accuracy and quality of decisions taken. The difference between the modern and traditional approach is significant. In the traditional approach to the management (in particular with reference to research processes) the main stress is put on finding answers to the following questions:

- Which elements - of an organisation, process, etc. are not working properly?

- Which elements should be regarded as inappropriate?

- What are the reasons for that? 
The traditional approach does not always allow achieving satisfactory results; what is more, it does not always result in improving the existing situation. Within the scope of the contemporary approach, various types of principles, procedures or tools are elaborated. They allow, contrary to the traditional approach, enhancing the knowledge of the existing problem situation (Ares and Varela, 2018; Dźwigoł et al., 2020a, 2020b; Dementyev and Kwilinski, 2020; Dźwigoł and Dźwigoł-Barosz, 2020; Kharazishvili et al., 2020; Kwilinski et al., 2020; Boiko et al., 2019; Chygryn et al., 2020; Czyżewski et al., 2019; Cyfert et al., 2020; Czakon et al., 2020; Dalevska et al., 2019; Dyduch, 2019a, 2019b; Gorynia, 2019; Gorynia et al., 2019; Klimas et al., 2020; Kwilinski 2017, 2018a, 2018b, 2018c, 2019; Kwilinski et al., 2019a, 2019b, 2019c; Lakhno et al., 2018; Miskiewicz, 2018, 2019, 2020; Miśkiewicz and Wolniak, 2020; Pająk et al., 2016, 2017; Saługa et al., 2020; Savchenko et al., 2019; Tkachenko et al., 2019a, 2019b, 2019c, 2019d; Trąpczyński et al., 2019; Yakubovskiy et al., 2017; Zastempowski, 2020). To this end, one may adopt the following perspective - the Positive Organizational Scholarship (SOP). Upon its implementation, one needs to pose a basic question, i.e.: Why are some employees so ineffective? Then, the following questions are asked:

- Why is it so?

- What are the reasons for such a phenomenon?

As a result of the applied SOP perspective, one will find an answer to the following question - what needs to be done to achieve the desired state, i.e. what needs to be done to be good at something and how to achieve perfection.

In the literature on management sciences, the necessity to apply numerous self-verifying and self-correcting methods has been highlighted many a time (Denzin, 1970; Harrington, 2016). Furthermore, there occurred a phenomenon of methodological pluralism. It has advocated that in order to solve a research problem, one should be ready to apply research methods derived from various disciplines and theoretical approaches. It means that 'the multitude of ways in which the world is perceived shall be combined with multitude and diversity of ways, methods, evaluation techniques, and attempts to transform the world.' However, it very often causes anarchism and methodological eclecticism. With reference to the foregoing, in order to achieve reliable research results, it is necessary to analyse in details a research problem, and consequently select such research methods that would facilitate the avoidance of the above-mentioned phenomena.

Conclusions derived from an ongoing analysis of national and foreign literature dealing with methodology of conducting a research process (Boland et al., 2017) show a deficit in empiric approaches to the quality of research processes, where, as a result of transformations over several years in management methods, it is difficult, as early as at the stage of defining a research problem, to select just one method that would allow diagnosing a problem fully and comprehensively. That is why the research, as determined in the article, is aimed at selecting factors that would influence the quality of the research process, as an element supporting the ongoing methodology-related approaches. 


\section{Research method}

Conclusions derived from an ongoing analysis of literature dealing with the methodology of conducting a research process showed a deficit in empiric approaches to the quality of research processes. Thus, the research problem is formulated as follows: What factors determine the quality of the research process in management sciences? In view of the above, the following main objective has been undertaken in the paper: to identify the factors influencing the quality of the research process as a complementary element of the existing methodological approaches.

As a result of the set goal, the research was carried out using an anonymous questionnaire. The research study was carried out from October 2016 to April 2018.

The structure of the questionnaire in the research part involved both open, rank questions, and questions based on the 5-point Likert scale. Within the scope of the latter, the respondents were obliged to classify a particular answer as strongly agree (5), agree (4), neither agree nor disagree (3), disagree (2), strongly disagree (1), with reference to each of proposed assumptions (Dźwigoł, 2018).

The research covered theoreticians of management sciences, being a target group. The group consisted of:

- 272 foreign universities having faculties and/or units dealing with management sciences,

- 21,024 foreign academic staff connected to the management sciences,

- 93 national universities having faculties and/or units dealing with management sciences,

- 2,307 national academic staff connected with the management sciences,

- 52 foreign companies,

- 183 national companies.

The size of a research sample, necessary to determine a representative character of the research, was determined on the basis of the following assumptions:

- the $\mathrm{p}$ fraction ratio was set to $50 \%$,

- the amount of an error related to the fraction ratio was set to $5 \%$,

- statistical significance $\alpha=0.05$. 
On the basis of the above-mentioned assumptions, the requested sample size formula will be simplified, and look as follows (Kukuła, 2007):

$n_{p}=\frac{u_{\alpha}^{2} * p(1-p)}{b_{p}^{2}}=\frac{u_{\alpha}^{2}}{4 b_{p}^{2}}=\frac{1.96^{2}}{4 * 0.05^{2}}=384.16$

where:

$n_{p}$ - requested sample size,

$u_{\alpha}$ - the amount of cumulative normal distribution derived from statistical tables,

$\mathrm{p}$ - fraction ratio,

$\mathrm{b}$ - the size of the fraction ratio error.

As a result of the research effort, 401 representatives of management science theorists were surveyed, thus the condition determining the representative character of the research sample was met.

In the surveyed group of scientists, Polish universities amounted to $32 \%$, whereas foreign universities accounted for $33 \%$. As to the remaining part of the research group $(35 \%)$, no academic unit was indicated. The most common areas of sciences in which the researchers were involved where, among others: strategic management, company management, knowledge and innovation management, as well as methodics of the research on organisations.

In order to assess factors that determine the quality of research processes in management sciences, one applied a commonly used method of principal component analysis (PCA), also known as factor analysis (Trajer, Paszek, Iwan, 2012). The main aim of conducting the factor analysis was to identify all factors being directly correlated to a given set of variables, while maintaining, at the same time, the greatest amount of information contained in initial variables, which was then followed by their reduction.

A statistical analysis of results was conducted by means of a statistical programme named Statistica 13 (statsoft.pl). The software in question has been in widespread use for the analysis of statistical data (Malska, 2017; Fojud et al., 2017).

\section{Research results}

The analysis of research results included their preparation using descriptive statistics tools. It should be emphasized that the obtained results are preliminary in nature and are the basis for further in-depth research, which is the subject of other studies.

In compliance with method-related assumptions, referring to the fulfilment of basic requirements for carrying out the factor analysis, one should take the following steps, destined to prove that the method in question was correctly selected: 
- Verification of a number of variables against a number of respondents taking part in the study,

- The Bartlett test (of sphericity),

- The KMO and MSA measures.

In the beginning, the condition referring to the number of observations and variables was studied. In the case in question, 33 variables and 401 surveyed respondents were analysed, which means that the condition was met.

For the purpose of performing the Bartlett test, the following zero hypothesis $\left(\mathrm{H}_{0}\right)$ and alternative hypothesis $\left(\mathrm{H}_{1}\right)$ were applied):

$\mathrm{H}_{0}$ - the matrix containing variable correlations is a unit matrix.

$\mathrm{H}_{1}$ - the matrix containing variable correlations is not a unit matrix.

Table 1.

The Bartlett test (of sphericity) results are relevant when $p<0.05$ ). The author's own study

\begin{tabular}{|c|c|c|c|}
\hline Empirical Chi & Levels of freedom & p-value & Theoretical $^{\mathbf{C h}} \mathbf{~}^{\mathbf{2}}$ \\
\hline 4830.79 & 528 & $<0.001$ & 582.56 \\
\hline
\end{tabular}

Since the empirical chi ${ }^{2}$ exceeds the theoretical $\mathrm{chi}^{2}$, the zero hypothesis is rejected in favour of the alternative hypothesis. It therefore transpires that variables can be subject to the factor analysis. The KMO Measure (Kaiser-Meyer-Olkin Measure of Sampling Adequacy), in the covered study, amounts to 0.835 . Analysing the results obtained, the MSA (Measure of Sampling Adequacy) was additionally checked. After the analysis, it can be concluded that each of the questions meets the MSA measurement threshold mentioned above.

Table 2.

Results of the MSA analysis. The author's own study

\begin{tabular}{|l|c|c|}
\hline Question & $\begin{array}{c}\text { Variable } \\
\text { number }\end{array}$ & $\begin{array}{c}\text { MSA } \\
\text { reference }\end{array}$ \\
\hline $\begin{array}{l}\text { Is the Management science discipline destined to support practical aspects of the } \\
\text { economic life? }\end{array}$ & P1 & 0.850 \\
\hline $\begin{array}{l}\text { Should a researcher provide models of effective organisation- and management- } \\
\text { related solutions? }\end{array}$ & P2 & 0.805 \\
\hline Should a researcher provide methods to implement models of effective solutions? & P3 & 0.818 \\
\hline $\begin{array}{l}\text { Is it necessary that the research studies, carried out within the scope of the } \\
\text { Management science discipline, be practically and theoretically set? }\end{array}$ & 0.869 \\
\hline $\begin{array}{l}\text { Is the instability of statements the main drawback connected with the Management } \\
\text { science? }\end{array}$ & P5 & 0.852 \\
\hline $\begin{array}{l}\text { Does the research cover, in most cases, those variables which depend on various } \\
\text { conditions: operating conditions, weather and environmental conditions, legal or } \\
\text { social conditions, etc? }\end{array}$ & P6 & 0.883 \\
\hline $\begin{array}{l}\text { Does the complexity of research objects (e.g. companies) have a negative impact on } \\
\text { the credibility of research findings? }\end{array}$ & P7 & 0.846 \\
\hline $\begin{array}{l}\text { Does the application of qualitative factors, difficult to measure, affect the quality of } \\
\text { a research process? }\end{array}$ & P8 & 0.817 \\
\hline $\begin{array}{l}\text { Are the advocated and applied methods assessed differently by management } \\
\text { theorists and practitioners? }\end{array}$ & P9 & 0.790 \\
\hline
\end{tabular}


Cont. table 2.

\begin{tabular}{|c|c|c|}
\hline $\begin{array}{l}\text { Are there any problems in terms of verifiability of findings of research studies, } \\
\text { carried out in the Management science discipline? }\end{array}$ & $\mathrm{P} 10$ & 0.786 \\
\hline $\begin{array}{l}\text { Should the co-operation between science and business practice be of strategic } \\
\text { character in the process of managing a modern company? }\end{array}$ & P11 & 0.873 \\
\hline $\begin{array}{l}\text { In the Management sciences, does the time between posing a problem, analysing } \\
\text { and finding a solution to the problem, and implementing the said solution have } \\
\text { a negative impact on the effectiveness of the solution? }\end{array}$ & $\mathrm{P} 12$ & 0.909 \\
\hline $\begin{array}{l}\text { Is there universalism of elaborated concepts, solutions to problems in the } \\
\text { Management sciences? }\end{array}$ & $\mathrm{P} 13$ & 0.794 \\
\hline Is the methodological triangulation a prerequisite in research processes? & $\mathrm{P} 14$ & 0.802 \\
\hline Should qualitative methods in research processes be completed with case studies? & $\mathrm{P} 15$ & 0.865 \\
\hline $\begin{array}{l}\text { Is it necessary, in order to make the research reliable, to verify the elaborated } \\
\text { methods, procedures and models in practice? }\end{array}$ & P16 & 0.860 \\
\hline Can pilot studies affect the direction of a research process? & $\mathrm{P} 17$ & 0.875 \\
\hline $\begin{array}{l}\text { Is it necessary to create a model, procedure, tool or approach for the sake of } \\
\text { a research process? }\end{array}$ & P18 & 0.885 \\
\hline $\begin{array}{l}\text { Is it possible for a researcher to match chosen methods to the character of the } \\
\text { research study in question? }\end{array}$ & P19 & 0.701 \\
\hline $\begin{array}{l}\text { Does a researcher have an impact on combining qualitative and quantitative } \\
\text { methods in a research process? }\end{array}$ & $\mathrm{P} 20$ & 0.720 \\
\hline Do pilot studies affect the course of a research process? & P21 & 0.862 \\
\hline $\begin{array}{l}\text { Does the elaboration of models, procedures, tools or approaches in the research } \\
\text { process guarantee the credibility of results? }\end{array}$ & $\mathrm{P} 22$ & 0.884 \\
\hline Is it necessary to elaborate assumptions in order to create research methodics? & $\mathrm{P} 23$ & 0.884 \\
\hline $\begin{array}{l}\text { Do the recommendation for management science and practice, elaborated on the } \\
\text { basis of research results, improve the quality of science and practice? }\end{array}$ & $\mathrm{P} 24$ & 0.845 \\
\hline $\begin{array}{l}\text { Does the elaborated model, procedure, tool or approach to the methods selected for } \\
\text { a research process considerably affect the quality and application of research } \\
\text { results? }\end{array}$ & $\mathrm{P} 25$ & 0.823 \\
\hline $\begin{array}{l}\text { Is it necessary, upon determining the research problem, to analyse selected } \\
\text { qualitative and quantitative methods, in order to make a preliminary selection? }\end{array}$ & P26 & 0.840 \\
\hline Are pilot studies an integral component of each research process? & $\mathrm{P} 27$ & 0.801 \\
\hline $\begin{array}{l}\text { Is the verification of elaborated methods, models or procedures a prerequisite to } \\
\text { combine management science and practice? }\end{array}$ & $\mathrm{P} 28$ & 0.856 \\
\hline Does the methodological triangulation support research processes? & P29 & 0.843 \\
\hline Does a case study allow to perform an in-depth analysis of a research process? & $\mathrm{P} 30$ & 0.813 \\
\hline $\begin{array}{l}\text { Should the expert group assessment be regarded as a basic method of evaluating } \\
\text { trends of the carried-out research? }\end{array}$ & $\mathrm{P} 31$ & 0.849 \\
\hline $\begin{array}{l}\text { Is it important to carry out observations of research studies in natural conditions, } \\
\text { in which a researcher co-operates with researched subjects? }\end{array}$ & P32 & 0.794 \\
\hline $\begin{array}{l}\text { What is the importance of observation-interventions conducted with the scope of } \\
\text { managerial activity in the researched subjects, whereas a researcher can directly } \\
\text { influence the decisions taken? }\end{array}$ & P33 & 0.766 \\
\hline
\end{tabular}

In this particular case, the research process is the central variable. On the basis of the presented results, 8 factors have been identified that meet the mentioned Kaiser criterion and it was concluded that this number is sufficient to illustrate the problem. 


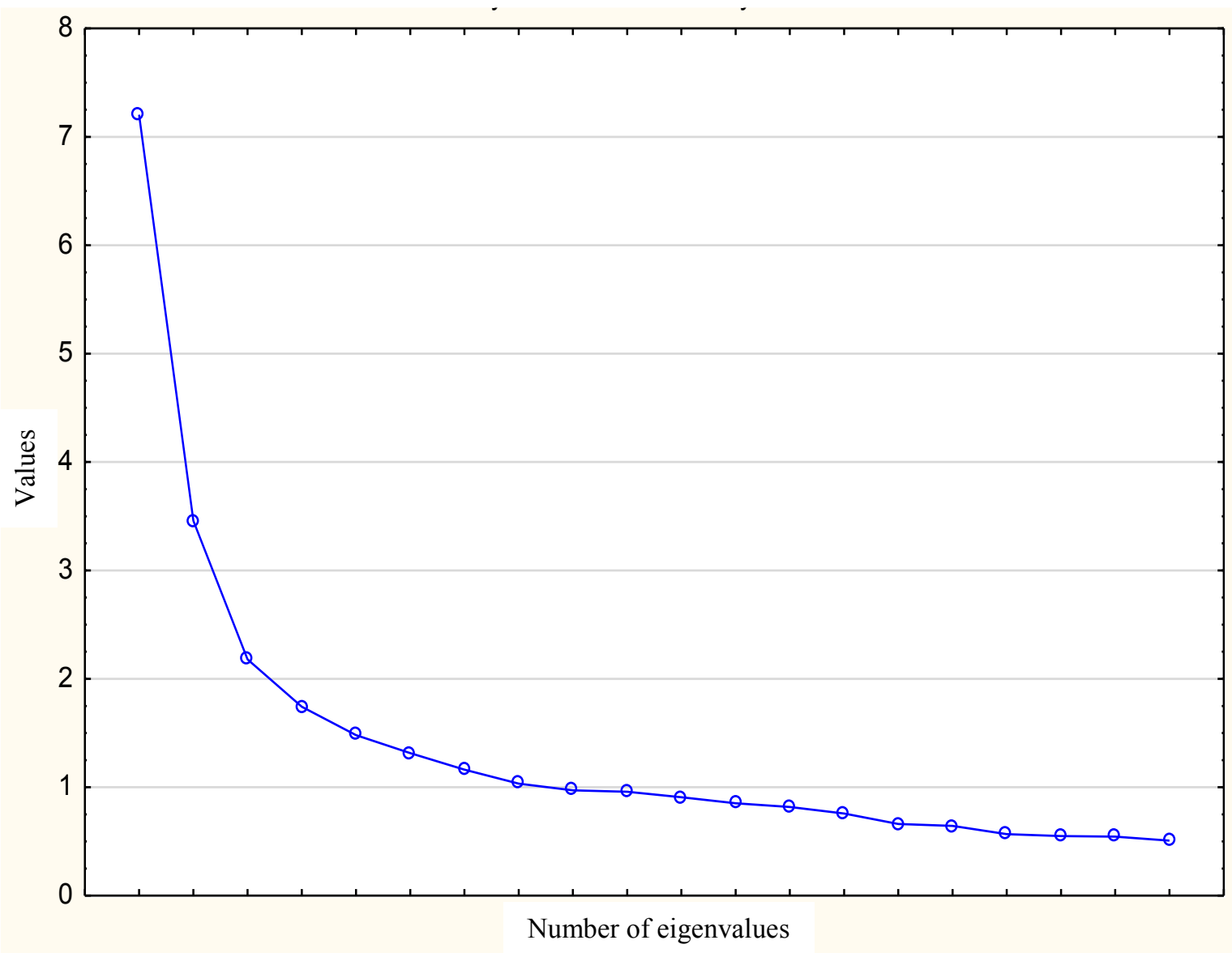

Figure 1. The Scree Chart for variables under research. The author's own study.

In the analysed case, the factor rotation was performed with the use of the EQUAMAX method which allows distributing, in a uniform way, a variance between factors. The method also reduces the number of factors required for the sake of explaining variances. The threshold loading was set to 0.5 . In the case in question, by means of 8 defined factors, one is able to explain $59.32 \%$ of the research process.

1. Application and purposefulness in practice $(\mathrm{P} 1-\mathrm{P} 4)$ - the factor understood as an opportunity to fulfil a scientific target, i.e. opportunity to implement the research process in question into the operation of companies and real economic life.

2. Impact of diversity of problems onto the process (P5-P8; P11; P30) - the factor understood as an answer to the question how the selected research problem will determine further research actions?

3. Influence of a researcher (P19-P21) - the factor that associates with the scope of free decisions taken by the researcher while dealing with a problem.

4. Unique character of a scientific discipline (P9-P10) - the factor shows differences in how practitioners and theoreticians evaluate the selected methods, which makes it difficult to assess, in an objective way, the verifiability of the conducted research studies. 
5. Importance of observations (P32-P33) - the factor shows the impact of two types of observation. The first type of observation deals with the opportunity to co-operate with other entities, the second types involves, the so-called observation followed by a possible intervention.

6. Completeness of the process (P24-P26) - the factor is understood as an opportunity to divide the research process into stages that form a complementary whole, i.e.: combining qualitative and quantitative methods, elaborating a unique tool, model, approach to the way a method or procedure is selected, indicating recommendations as to scientific and practical aspects.

7. A type of a supported process (P15; P17; P21) - the factor is understood as an impact on the course and management of the research process by means of pilot studies and case studies.

8. The need for triangulation and universalism of the conducted research (P13; P14) - the factor shows, to a certain extent, a forced requirement for the management sciences to develop. However, a failure in meeting the requirements does not necessarily mean a failure in finding an original solution to the research problem.

\section{Summary and research conclusions}

The aim of the article was to determine factors that would influence the quality of a research process, as an element that supplements currently used methodology-related approaches. As a result of research efforts, including conducted empirical studies, the main aim hereof and detailed aims were achieved. Upon the achievement of the aims and finding answers to research question, one was able to positively verify the adopted hypothesis.

Findings derived from the analysis of foreign and national literature on the methodology of conducting a research process include thoughts on transformations occurring over the years. The transformations covered the management methods which allowed analysing conditions of organisations. The management methodology is constantly expanding by new methods, the latter being of diverse cognitive and practical effectiveness. A constant growth of diagnostic instruments has been dependent, mainly, on changes occurring in the environment; moreover, it is connected to the need to make use of more sophisticated and effective tools.

On the basis of the factor analysis, eight factors were identified. The factors, determining the quality of research processes, are as follows:

1. Practical application and purposefulness.

2. Influence of diverse research problems on the process.

3. Influence of a researcher on the research process.

4. Unique character of a scientific discipline. 
5. Importance of observations.

6. Completeness of the process.

7. Process assistance type.

8. Need for triangulation and universalism.

It needs to be borne in mind that, depending on a subject covered in doctoral or post-doctoral theses, some of the above-mentioned factors do not necessarily have to be reflected in science or practice, nor should their importance be ignored. The above-mentioned factors allow evaluating the quality of the research process in question. The notion of the quality of the research process in management sciences should be understood as an opportunity to verify a level of execution and coherence of aims of theses with research problems and conclusions contained therein.

\section{References}

1. Ares, G. and Varela, P. (Eds.) (2018). Methods in Consumer Research, Volume 2: Alternative Approaches and Special Applications. Duxford: Woodhead Publishing, Elsevier.

2. Boiko, V., Kwilinski, A., Misiuk, M., \& Boiko, L. (2019). Competitive Advantages of Wholesale Markets of Agricultural Products as a Type of Entrepreneurial Activity: The Experience of Ukraine and Poland. Economic Annals - XXI, 175(1-2), 68-72. https://doi.org/10.21003/ea.V175-12.

3. Boland, A., Cherry, G. and Dickson, R. (Eds.) (2017). Doing a Systematic Review: A Student's Guide. London: Sage.

4. Chygryn, O., Bilan, Y., \& Kwilinski, A. (2020). Stakeholders of Green Competitiveness: Innovative Approaches for Creating Communicative System. Marketing and Management of Innovations, 3, 356-368. https://doi.org/10.21272/mmi.2020.3-26.

5. Coghlan, D. and Shani, A.B. (Eds.) (2016). Action Research in Business and Management (Fundamentals of Applied Research). London: Sage.

6. Cyfert, S., Glabiszewski, W., Krzakiewicz, K., \& Zastempowski, M. (2020). The Importance of Dynamic Capabilities in the Processes of Alignment of Chemical Industry Enterprises to Changes in the Environment. Przemyst Chemiczny, 99(6), 2020, 953-956.

7. Czakon, W., Kawa, A., Scott, S. (2020). Network Orientation of Logistics Service Providers: The Construct, Dimensionality and Measurement Scale. International Journal of Logistics Research and Applications, 23(5), 474-492. https://doi.org/10.1080/ 13675567.2019.1705260. 
8. Czyżewski, B., Matuszczak, A., \& Miskiewicz, R. (2019). Public Goods Versus the Farm Price-Cost Squeeze: Shaping the Sustainability of the EU's Common Agricultural Policy. Technological and Economic Development of Economy, 25(1), 82-102. https://doi.org/ 10.3846/tede.2019.7449

9. Dalevska, N., Khobta, V., Kwilinski, A., \& Kravchenko, S. (2019). A Model for Estimating Social and Economic Indicators of Sustainable Development, Entrepreneurship and Sustainability Issues, 6(4), 1839-1860. https://doi.org/10.9770/jesi.2019.6.4(21)

10. Dementyev, V.V., \& Kwilinski, A. (2020). Institutional Component of Production Costs. Journal of Institutional Studies, 12(1), 100-116. https://doi.org/10.17835/20766297.2020.12.1.100-116.

11. Denzin, N. (1970). The Research Act: Theorethical Introduction to Sociological Methods. Chicago: Aldine.

12. Dyduch, W. (2019). Entrepreneurial Strategy Stimulating Value Creation: Conceptual Findings and Some Empirical Tests. Entrepreneurial Business and Economics Review, 7(3), 65-82. https://doi.org/10.15678/EBER.2019.070304.

13. Dyduch, W. (2019). Organizational Design Supporting Innovativeness. Przeglad Organizacji, 6, 16-23. https://doi.org/10.33141/po.2019.06.02.

14. Dźwigoł, H. (2018). Modern Research Processes in Management Sciences. Methodological and Methodical Conditions, in Polish [Wspótczesne procesy badawcze w naukach o zarzadzaniu. Uwarunkowania metodyczne i metodologiczne]. Warszawa: PWN.

15. Dźwigoł, H. (2019a). Research Methods and Techniques in New Management Trends: Research Results. Virtual Economics, 2(1), 31-48. https://doi.org/10.34021/ ve.2019.02.01(2).

16. Dźwigoł, H. (2019b). The Concept of the System Approach of the Enterprise Restructuring Process. Virtual Economics, 2(4), 46-70. https://doi.org/10.34021/ve.2019.02.04(3).

17. Dźwigoł, H. (2020a). Innovation in Marketing Research: Quantitative and Qualitative Analysis. Marketing and Management of Innovations, 1, 128-135. http://doi.org/10.21272/ mmi.2020.1-10.

18. Dźwigoł, H. (2020b). Methodological and Empirical Platform of Triangulation in Strategic Management. Academy of Strategic Management Journal, 19(4), 1-8.

19. Dźwigoł, H. (2020c). Interim Management as a New Approach to the Company Management. Review of Business and Economics Studies, 8(1), 20-26. https://doi.org/10.26794/2308-944X-2020-8-1-20-26.

20. Dźwigoł, H., \& Dźwigoł-Barosz, M. (2018). Scientific Research Methodology in Management Science. Financial and Credit Activity: Problems of Theory and Practice, 2(25), 424-437. https://doi.org/10.18371/fcaptp.v2i25.136508.

21. Dźwigoł, H., \& Dźwigoł-Barosz, M. (2020). Sustainable Development of the Company on the Basis of Expert Assessment of the Investment Strategy. Academy of Strategic Management Journal, 19(5), 1-6. 
22. Dźwigoł, H., \& Wolniak, R. (2018). Controlling in the management process of a chemical industry production company [Controlling $\mathrm{W}$ procesie zarządzania chemicznym przedsiębiorstwem produkcyjnym]. Przemyst Chemiczny, 7, 114933. https://doi.org/10.15199/62.2018.7.15.

23. Dźwigoł, H., Dźwigoł-Barosz, M., \& Kwilinski, A. (2020b). Formation of Global Competitive Enterprise Environment Based on Industry 4.0 Concept. International Journal of Entrepreneurship, 24(1), 1-8.

24. Dźzwigoł, H., Dźwigoł-Barosz, M., Miskiewicz, R., \& Kwilinski, A. (2020a). Manager Competency Assessment Model in the Conditions of Industry 4.0. Entrepreneurship and Sustainability Issues, 7(4), 2630-2644. https://doi.org/10.9770/jesi.2020.7.4(5).

25. Dźwigoł, H., Dźwigoł-Barosz, M., Zhyvko, Z., Miśkiewicz, R., \& Pushak H. (2019a). Evaluation of the Energy Security as a Component of National Security of the Country. Journal of Security and Sustainability Issues, 8(3), 307-317. https://doi.org/10.9770/ jssi.2019.8.3(2).

26. Dźwigoł, H., Shcherbak, S., Semikina, M., Vinichenko, O., \& Vasiuta, V. (2019b). Formation of Strategic Change Management System at an Enterprise. Academy of Strategic Management Journal, 18(SI1), 1-10.

27. Fojud, A., Boniecki, P., Zaborowicz, M., Lisak, D., Ślósarz, P., Stanisz, M., Strzeliński, P. and Konieczny, A. (2017). Project of a computer system supporting extraction of the characteristics of pork half-carcases. Journal of Research and Application in Agricultural Engineering, 62(3), 87-92.

28. Gerring, J. (2017). Case Study Research: Principles and Practices (Strategies for Social Inquiry). New York: Cambridge University Press.

29. Gorynia, M. (2019). Competition and Globalisation in Economic Sciences. Selected Aspects. Economics and Business Review, 5(3), 118-133. https://doi.org/10.18559/ ebr.2019.3.7.

30. Gorynia, M., Trąpczyński, P., \& Bytniewski, S. (2019). The Concepts of Strategy and Business Models in Firm Internationalization Research: Towards a Research Agenda. International Entrepreneurship Review, 5(2), 7-21. https://doi.org/10.15678/ ier.2019.0502.01.

31. Harrington, H.J. and Voehl, F. (Eds.) 2016. The Innovation Tools Handbook, Volume 1: Organizational and Operational Tools, Methods, and Techniques that Every Innovator Must Know. USA, Boca Raton, FL: CRC Press.

32. Karna, A., Richter, A., and Riesenkampff, E. (2016). Revisiting the role of the environment in the capabilities-financial performance relationship: a meta-analysis, Strategic Management Journal, 37, 1154-1173.

33. Kharazishvili, Y., Kwilinski, A., Grishnova, O., Dzwigol, H. (2020). Social Safety of Society for Developing Countries to Meet Sustainable Development Standards: Indicators, 
Level, Strategic Benchmarks (with Calculations Based on the Case Study of Ukraine). Sustainability, 12(21), 8953. https://doi.org/10.3390/su12218953.

34. Klimas, P., Czakon, W., Kraus, S., Kailer, N., \& Maalaoui, A. (2020). Entrepreneurial Failure: A Synthesis and Conceptual Framework of its Effects. European Management Review. https://doi.org/10.1111/emre.12426.

35. Kwilinski, A. (2017). Development of Industrial Enterprise in the Conditions of Formation of Information Economics. Thai Science Review, Autumn 2017, 85-90.

36. Kwilinski, A. (2018a). Trends of Development of the Information Economy of Ukraine in the Context of Ensuring the Communicative Component of Industrial Enterprises. Economics and Management, 1(77), 64-70.

37. Kwilinski, A. (2018b). Mechanism of Formation of Industrial Enterprise Development Strategy in the Information Economy. Virtual Economics, 1(1), 7-25. https://doi.org/10.34021/ve.2018.01.01(1)

38. Kwilinski, A. (2018c). Mechanism of Modernization of Industrial Sphere of Industrial Enterprise in Accordance with Requirements of the Information Economy. Marketing and Management of Innovations, 4, 116-128. http://doi.org/10.21272/mmi.2018.4-11.

39. Kwilinski, A. (2019). Implementation of Blockchain Technology in Accounting Sphere. Academy of Accounting and Financial Studies Journal, 23(SI2), 1-6.

40. Kwilinski, A., Dalevska, N., Kravchenko, S., Hroznyi, I., \& Kovalenko, I. (2019a). Formation of the Entrepreneurship Model of E-Business in the Context of the Introduction of Information and Communication Technologies. Journal of Entrepreneurship Education, 22(SI1), 1-7.

41. Kwilinski, A., Dzwigol, H., \& Dementyev, V. (2020e). Model of Entrepreneurship Financial Activity of the Transnational Company Based on Intellectual Technology. International Journal of Entrepreneurship, 24(1), 1-8.

42. Kwilinski, A., Ruzhytskyi, I., Patlachuk, V., Patlachuk, O., \& Kaminska, B. (2019b). Environmental Taxes as a Condition of Business Responsibility in the Conditions of Sustainable Development. Journal of Legal, Ethical and Regulatory Issues, 22(SI2), 1-6.

43. Kwilinski, A., Volynets, R., Berdnik, I., Holovko, M., \& Berzin, P. (2019c). E-Commerce: Concept and Legal Regulation in Modern Economic Conditions. Journal of Legal, Ethical and Regulatory Issues, 22(SI2), 1-6.

44. Kwilinski, A., Vyshnevskyi, O., \& Dźwigoł H. (2019d). Digitalization of the EU Economies and People at Risk of Poverty or Social Exclusion. Journal of Risk and Financial Management, 13(7), 142. https://doi.org/10.3390/jrfm13070142.

45. Lakhno, V., Malyukov, V., Bochulia, T., Hipters, Z., Kwilinski, A., \& Tomashevska, O. (2018). Model of Managing of the Procedure of Mutual Financial Investing in Information Technologies and Smart City Systems. International Journal of Civil Engineering and Technology, 9(8), 1802-1812. 
46. Miśkiewicz, R, Wolniak, R. (2020). Practical Application of the Industry 4.0 Concept in a Steel Company. Sustainability, 12(14), 5776. https://doi.org/10.3390/su12145776.

47. Miskiewicz, R. (2018). The Importance of Knowledge Transfer on the Energy Market. Polityka Energetyczna, 21(2), 49-62. http://dx.doi.org/10.24425\%2F122774.

48. Miskiewicz, R. (2019). Challenges Facing Management Practice in the Light of Industry 4.0: The Example of Poland. Virtual Economics, 2(2), 37-47. https://doi.org/10.34021/ ve.2019.02.02(2).

49. Miskiewicz, R. (2020). Internet of Things in Marketing: Bibliometric Analysis. Marketing and Management of Innovations, 3, 371-381. http://doi.org/10.21272/mmi.2020.3-27.

50. Mooi, E., Sarstedt, M. and Mooi-Reci, I. (2018). Market research. The process, data, and methods using stata. Singapore: Springer Nature.

51. O'Leary, Z. and Hunt, J.S. (2016). Workplace Research: Conducting small-scale research in organizations. London: Sage.

52. Pająk, K., Kamińska, B., \& Kvilinskyi, O. (2016). Modern Trends of Financial Sector Development under the Virtual Regionalization Conditions. Financial and Credit Activity: Problems of Theory and Practice, 2(21), 204-217. https://doi.org/10.18371/ fcaptp.v2i21.91052.

53. Pająk, K., Kvilinskyi, O., Fasiecka, O., \& Miskiewicz, R. (2017). Energy security in regional policy in Wielkopolska region of Poland. Economics and Environment, 2(61), 122-138.

54. Petrova, V.M. (Eds.) (2018). Advances in Engineering Research. New York: Nova Science Pub Inc.

55. Punch, K.F. (2016). Developing Effective Research Proposals. London: Sage.

56. Quian, D. (2018). Adaptive Control: Methods, Applications and Research. New York: Nova Science Publishers, Inc.

57. Saługa, P.W., Szczepańska-Woszczyna, K., Miśkiewicz, R., \& Chłąd, M. (2020). Cost of Equity of Coal-Fired Power Generation Projects in Poland: Its Importance for the Management of Decision-Making Process. Energies, 13(18), 4833, https://doi.org/10.3390/ en13184833.

58. Savchenko, T., Basiurkina, N., Rodina, O., \& Kwilinski, A. (2019). Improvement of the Assessment Methods of Product Competitiveness of the Specialized Poultry Enterprises. Management Theory and Studies for Rural Business and Infrastructure Development, 41(1), 43-61, https://doi.org/10.15544/mts.2019.05.

59. Sloan, L. and Quan-Haase, A. (Eds.) (2017). The SAGE Handbook of Social Media Research Methods. London: Sage.

60. Teece, D.J., Pisano, G., and Shuen, A. (1997). Dynamic capabilities and strategic management. Strategic Management Journal, 18(7), 509-533.

61. Tkachenko, V., Kwilinski, A., Kaminska, B., Tkachenko, I., \& Puzyrova, P. (2019d). Development and Effectiveness of Financial Potential Management of Enterprises in 
Modern Conditions. Financial and Credit Activity: Problems of Theory and Practice, 3(30), 85-94. https://doi.org/10.18371/fcaptp.v3i30.179513.

62. Tkachenko, V., Kwilinski, A., Klymchuk, M., \& Tkachenko, I. (2019b). The EconomicMathematical Development of Buildings Construction Model Optimization on the Basis of Digital Economy. Management Systems in Production Engineering, 27(2), 119-123. http://doi.org/10.1515/mspe-2019-0020.

63. Tkachenko, V., Kwilinski, A., Korystin, O., Svyrydiuk, N., \& Tkachenko I. (2019a). Assessment of Information Technologies Influence on Financial Security of Economy. Journal of Security and Sustainability, 8(3), 375-385. http://doi.org/10.9770/ jssi.2019.8.3(7).

64. Tkachenko, V., Kwilinski, A., Tkachenko, I., \& Puzyrova, P. (2019c). Theoretical and Methodical Approaches to the Definition of Marketing Risks Management Concept at Industrial Enterprises. Marketing and Management of Innovations, 2, 228-238. http://doi.org/10.21272/mmi.2019.2-20.

65. Trajer, J., Paszek, A. and Iwan, S. (2012). Zarzadzanie wiedza. Warszawa: PWE.

66. Trąpczyński, P., Gorynia, M., Nowak, J., Wolniak, R. (2019). EU Countries from Central and Eastern Europe, and the Investment Development Path Model: A New Assessment. Argumenta Oeconomica, 2(43), 385-406. https://doi.org/10.15611/aoe.2019.2.16.

67. Yakubovskiy, M., Liashenko, V., Kamińska, B., \& Kvilinskyi, O. (2017). Economy Modernization of Industrial Regions (Based on the Example of Ukraine). In P. Głowski, \& O. Kvilinskyi (Eds.), Economic Transformation in Ukraine: Comparative Analysis And European Experience (pp. 12-29). Warsaw: Consilium Sp. z o.o.

68. Zastempowski, M., Glabiszewski, W., Krukowski, K., Cyfert, S. (2020). Technological Innovation Capabilities of Small and Medium-Sized Enterprises. European Research Studies, 23(3), 460-474. 